\title{
Regeneração in vitro de melão, cv. 'Gaúcho’
}

\author{
In vitro regeneration of melon, cv. 'Gaúcho'
}

\section{Daiane Schmidt de Pinho ${ }^{\mathrm{I}^{*}}$ Maristela dos Santos Rey ${ }^{\mathrm{II}}$ Aniheb Vieira' ${ }^{\mathrm{I}}$ Rodrigo Danielowski $^{\mathrm{I}}$ Eugenia Jacira Bolacel Braga ${ }^{I}$ Jose Antonio Peters ${ }^{\mathrm{I}}$}

\section{RESUMO}

O objetivo do presente trabalho foi otimizar um protocolo de regeneração de explantes cotiledonares de melão, cultivar 'Gaúcho', avaliando a composição de meios de germinação e o tempo de permanência dos explantes nesses meios. Para isso, as sementes foram germinadas em meio MS semi-sólido contendo BAP ou ANA e sem esses reguladores de crescimento. As sementes permaneceram nesses meios por um, dois, três e quatro dias, sendo então seus cotilédones inoculados em meio MS contendo diferentes concentrações de BAP $(0,5$; 0,$9 ; 1,5$ e 2,0 $\left.\mathrm{mg} \mathrm{L}^{-1}\right)$. As maiores taxas de regeneração ocorreram nos cotilédones oriundos de sementes mantidas durante um e dois dias nos meios contendo 0,5 e $0,9 \mathrm{mg} \mathrm{L}^{-1}$ de BAP. O aumento da permanência dos explantes nos meios de germinação e as elevadas concentrações de BAP nos meios de regeneração diminuíram a capacidade organogênica dos explantes e incrementaram a formação de calos.

Palavras-chave: Cucumis melo L., meio de cultura, morfogênese.

\section{ABSTRACT}

The aim of the present study was to optimize a $\mathrm{cV}$. Gaucho melon cotyledon explant regeneration protocol, evaluating the germination media composition and the explant exposition period in these media. For this purpose, seeds were germinated in semi-solid MS medium containing either BAP or ANA, and without growth regulators. The seeds were kept in these media for one, two, three or four days; afterwards, their cotyledons were inoculated in MS medium containing different BAP concentrations $\left(0.5 ; 0.9 ; 1.5\right.$ and $\left.2.0 \mathrm{mg}^{-1}\right)$. The highest regeneration rates occurred with cotyledons from seeds which had been kept for one or two days in media containing 0.5 and $0.9 \mathrm{mg} \mathrm{L}^{-1}$ BAP. Both the increase in the explant exposition time in germination media and high BAP concentrations in regeneration media decreased explant organogenic capacity, and increased callus formation.

Key words: Cucumis melo L., culture medium, morphogenesis.

\section{INTRODUÇÃO}

O meloeiro (Cucumis melo L.) pertencente à família cucurbitaceae, é uma planta anual, herbácea e que apresenta frutos, classificados como climatéricos, altamente perecíveis em função da elevada percentagem de água e produção de etileno, baixa acidez e estrutura celular com grandes vacúolos (PECH et al., 1994). Para contornar essas dificuldades, a associação de técnicas bioquímicas, moleculares e de cultura in vitro possibilita a manipulação genética de plantas buscando o controle da expressão de genes envolvidos na biossíntese do etileno, possibilitando a obtenção de frutos com maturação retardada após a colheira (SILVA et al., 2004). Porém, para a aplicação dessas tecnologias, é de fundamental importância o desenvolvimento de métodos eficientes de regeneração de plantas, por meio da cultura de tecidos (DANG \& WEI, 2009).

A morfogênese, caracterizada pela emergência e formação de novos órgãos, resulta da interação de processos de indução, competência, determinação e diferenciação celular, os quais são influenciados pelo meio de cultivo, pelo genótipo, pelo tipo e pelas condições fisiológicas dos explantes, bem como pelas condições físicas do cultivo in vitro (LIU \& PIJUT, 2008).

Gemas e brotações de melão têm sido obtidas diretamente de cotilédones (NIEDZ et al., 1989) e folhas (YADAV et al., 1996) e indiretamente de calos derivados de cotilédones (MOLINA \& NUEZ, 1995) e hipocótilos

\footnotetext{
Instituto de Biologia, Departamento de Botânica, Universidade Federal de Pelotas (UFPel), Campus Universitário, s/nº, CP 354, 96010-900, Pelotas, RS, Brasil. E-mail: daiane_bio@yahoo.com.br. *Autor para correspondência.

ID Departamento de Fitossanidade, UFPel RS, Brasil.
} 
(KATHAL et al., 1995). Entre os diferentes tipos de explantes utilizados para regeneração em melão, secções foliares e cotiledonares têm apresentado maior taxa de regeneração (MOLINA \& NUEZ, 1995), embora os últimos apresentem resposta mais rápida (DIRKS \& VANBUGGENUM, 1989).

A capacidade regenerativa dos explantes é altamente dependente do genótipo utilizado, como tem sido detectado em vários trabalhos com melão (GRAY et al., 1993). Esse fato determina a necessidade do desenvolvimento de protocolos de regeneração para cultivares específicas visando à otimização da resposta in vitro e posterior aplicação de técnicas de biologia molecular e de transformação genética nestes, já que a maioria dos estudos realizados utilizam melões do grupo cantalupensis (GUIS et al., 1997; SILVA et al., 2004). Entretanto, no Brasil e mais precisamente no Sul do País, são cultivados melões pertencentes ao grupo saccharinus, que apresentam tamanho de frutos médios a grande, com polpa esbranquiçada ou amarelada e doce (KIRKBRIDE, 1993). Dentro desse grupo, enquadra-se a cultivar 'Gaúcho', que, embora tenha uma área de plantio bastante representativa, produz frutos altamente perecíveis, com uma vida de prateleira de quatro a seis dias, dependendo das condições de cultivo e do ponto de colheita.

Em consequência do exposto e visando, no futuro, à transformação genética, para aumentar a conservabilidade de seus frutos, o objetivo do presente trabalho foi otimizar um protocolo de regeneração de explantes cotiledonares de melão, cultivar 'Gaúcho', avaliando a composição de meios de germinação e o tempo de permanência dos explantes nestes meios.

\section{MATERIAL E MÉTODOS}

Sementes maduras de melão (Cucumis melo L.), cultivar 'Gaúcho', após retirada de seus tegumentos, foram desinfestadas por meio da imersão por 20 minutos em hipoclorito de sódio $2 \%$, juntamente com uma gota de detergente, seguida de três lavagens em água destilada e esterilizada, sob condições assépticas. Após a desinfestação, as sementes foram inoculadas em três meios de cultura semi-sólidos para germinação (Figura 1-A 1 ): G1- MS (MURASHIGE \& SKOOG, 1962); G2- MS $+2 \mathrm{mg} \mathrm{L}^{-1}$ ANA (ácido $\alpha$ naftalenoacético); G3- MS + 2mg L $\mathrm{m}^{-1} \mathrm{BAP}$ (6benzilaminopurina). $\mathrm{O} \mathrm{pH}$ dos meios de cultura foram ajustados para 5,8 antes da adição do ágar $\left(7 \mathrm{~g} \mathrm{~L}^{-1}\right) \mathrm{e}$ autoclavados durante 20 minutos a $121^{\circ} \mathrm{C}$ e $1,5 \mathrm{~atm}$. Após a inoculação das sementes, os frascos foram transferidos para câmara de crescimento, no escuro, por um, dois, três e quatro dias. Após cada período, os cotilédones foram separados, divididos em cinco partes (Figura 1- $\mathrm{A}_{2}$ ) e inoculados em meios de regeneração MS $+30 \mathrm{~g} \mathrm{~L}^{-1}$ sacarose $+0,2 \mathrm{mg} \mathrm{L}^{-1} \mathrm{ABA}$ (ácido abscísico) $+2,2 \mathrm{mg} \mathrm{L}^{-1} \mathrm{CaCl}_{2}$ (PEREIRA et al., 1999) acrescidos de diferentes concentrações de BAP $(0,5 ; 0,9 ; 1,5$ e 2,0mg $\mathrm{L}^{-1}$ ). Os meios contendo os explantes foram então transferidos para sala de crescimento com fotoperíodo de $16 \mathrm{~h}$, temperatura de $25 \pm 2^{\circ} \mathrm{C}$ e densidade de fluxo de fótons fotossinteticamente ativos de $36 \mu \mathrm{mol} \mathrm{m}^{-2} \mathrm{~s}^{-1}$, por 45 dias. Ao final do período de cultivo, foram avaliadas a presença de calos e a percentagem de explantes regenerativos, ou seja, que apresentavam gemas $(\leq 4,0 \mathrm{~mm})$ e/ou brotações $(>4,0 \mathrm{~mm})$.

Utilizou-se um delineamento experimental inteiramente casualizado, com tratamentos fatoriais $3 \times 4 \times 4$, sendo três meios de germinação, quatro períodos de permanência em meio de germinação e quatro concentrações de BAP no meio de regeneração. Foram utilizadas quatro repetições contendo 20 explantes em cada, totalizando 80 por tratamento. Os resultados foram submetidos à análise de variância por meio do pacote estatístico WINSTAT (MACHADO \& CONCEIÇÃO, 2003), e os dados foram transformados em $y=\operatorname{arcsen}(x / 100)^{1 / 2}$, em que $x$ representa o valor percentual obtido para as variáveis analisadas. Para a comparação dos resultados obtidos, adotou-se o teste de Tukey, a 5\% de probabilidade.

\section{RESULTADOS E DISCUSSÃO}

Observou-se que os explantes responderam diferentemente quanto à percentagem de regeneração em função dos dias que permaneceram nos meios de germinação (Figura 2), bem como pela concentração de BAP nos meios regenerativos (Figura 3).

Conforme pode ser visualizado na figura 2 , houve interação entre meios de germinação e dias em que as sementes permaneceram nestes meios. As melhores respostas foram obtidas em explantes provenientes de sementes inoculadas em meio MS (G1), sem regulador de crescimento, por um dia $(29,66 \%$ de explantes com gemas e/ou brotações). Os cotilédones oriundos de sementes cultivadas nos meios germinativos contendo ANA e BAP apresentaram respostas inferiores as do meio $\mathrm{G} 1$, com taxas de regeneração máximas de 16,56 e 14,06\%, respectivamente, quando cultivados por um dia nesses meios.

Resultados similares foram obtidos quando foram comparados o efeito das concentrações de BAP nos meios regenerativos e o tempo de permanência das sementes nos meios germinativos (Figura 3). Explantes oriundos de sementes cultivadas por um dia 


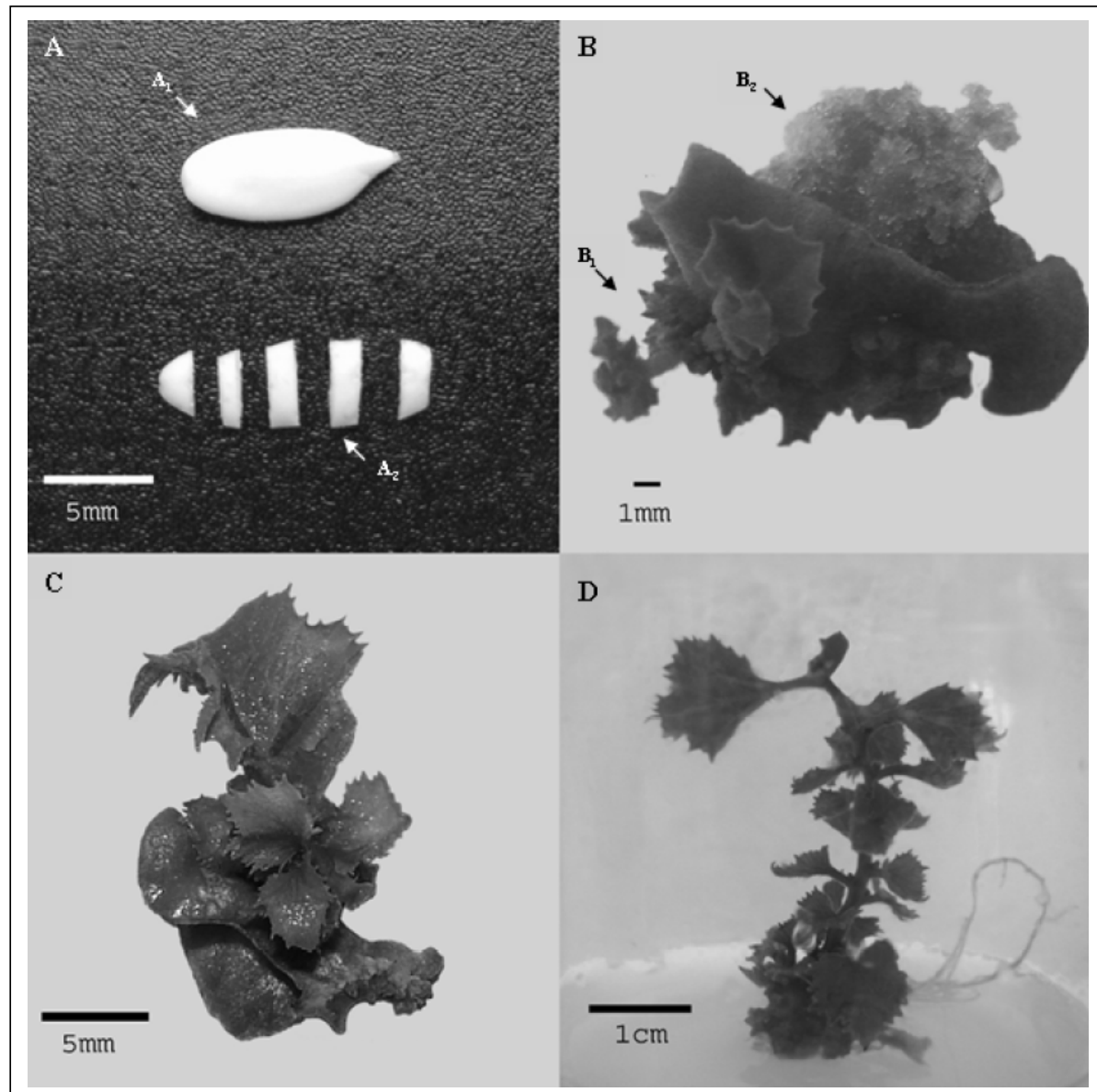

Figura 1 - Regeneração in vitro de explantes cotiledonares de melão da cultivar 'Gaúcho': sementes $\left(A_{1}\right)$; explantes $\left(A_{2}\right)$; gemas $\left(B_{1}\right)$; calos $\left(B_{2}\right)$; brotações $(C)$; e planta regenerada $(D)$.

nos meios germinativos e inoculados em meios regenerativos com baixas concentrações de $\operatorname{BAP}(0,5 \mathrm{e}$ $\left.0,9 \mathrm{mg} \mathrm{L}^{-1}\right)$ apresentaram melhores respostas, $\operatorname{com} 25,41$ e $27,08 \%$ de regeneração, respectivamente, ocorrendo, por outro lado, drásticas reduções nessas taxas quando os explantes foram cultivados por quatro dias nos meios germinativos ( 0 e 4,83\%). O aumento do período de permanência das sementes nos meios germinativos, além de induzir menor regeneração dos explantes, determinou uma sensibilidade menor destes às concentrações de BAP empregadas nos meios regenerativos (Figura 3). A taxa de regeneração diminuiu, em média, apenas $7,51 \%$ na concentração de $0,5 \mathrm{mg} \mathrm{L}^{-1}$ de BAP e $17,08 \%$ no meio contendo $2,0 \mathrm{mg} \mathrm{L}^{-1}$ do mesmo regulador de crescimento.

Como não ocorreu interação entre os meios germinativos e regenerativos, os efeitos dos meios germinativos tornam-se mais evidentes quando estes foram analisados separadamente (Figura 4). Observase que o meio G1 apresentou maior percentagem de explantes regenerantes $(29,66 \%), \quad$ sendo estatisticamente diferente dos meios MS contendo ANA e BAP, os quais não diferiram entre si.

Os resultados obtidos neste trabalho são similares aos de PEREIRA et al. (1999), os quais, utilizando a mesma cultivar e o mesmo meio de regeneração contendo $0,9 \mathrm{mg} \mathrm{L}^{-1}$ de BAP, obtiveram maiores taxas de regeneração (48,34\%) em cotilédones oriundos de sementes germinadas por 24 horas. No entanto, foram diferentes dos obtidos por NIEDZ et al. (1989), LESHEM (1989) e FICCANDENTI et al. (1995), os quais, trabalhando com melões tipo catalupensis, recomendaram a utilização de cotilédones com quatro a cinco dias de germinação. Tais diferenças podem estar relacionadas ao genótipo utilizado pelos referidos autores, o qual difere do material utilizado neste trabalho.

Diferentemente da taxa de regeneração de gemas e/ou brotações, a formação de calos foi incrementada com o aumento da permanência das sementes nos meios de germinação e com o aumento 


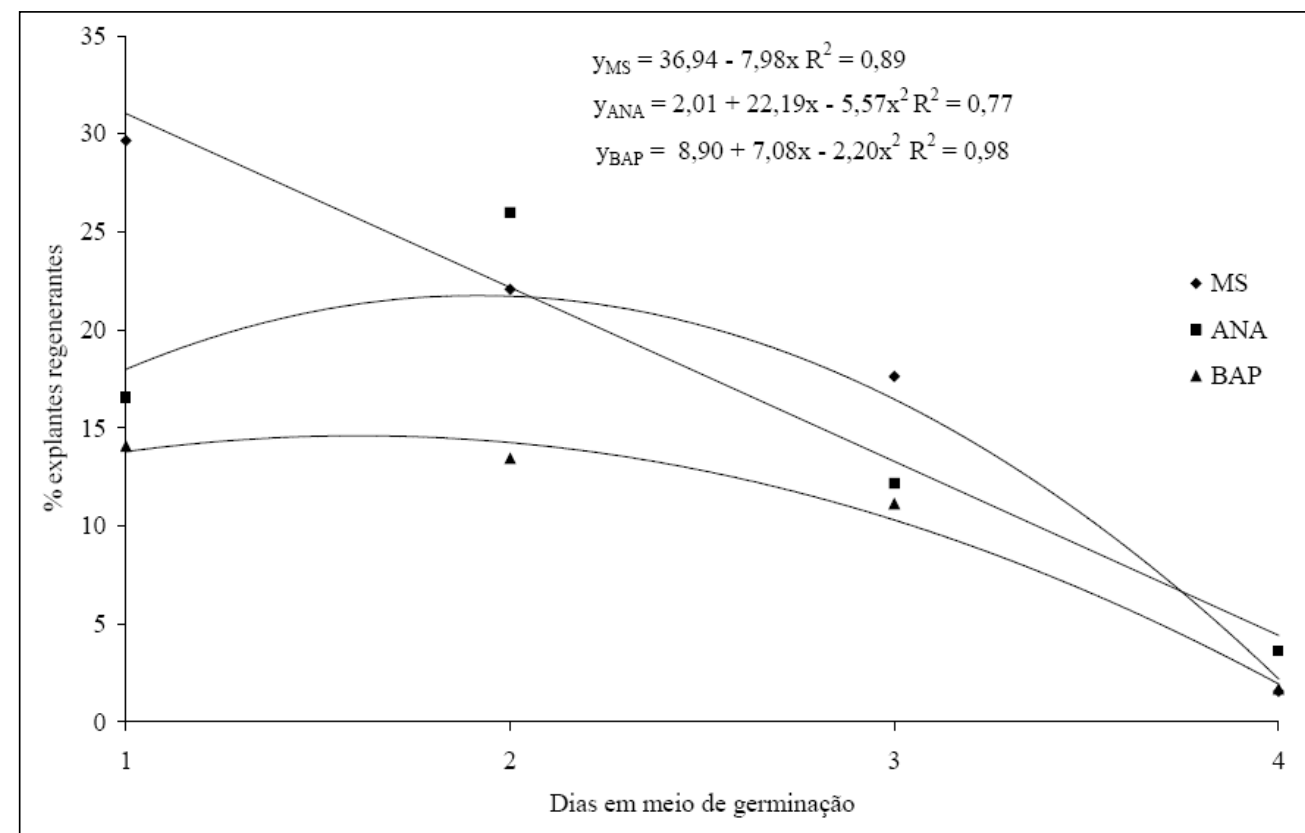

Figura 2 - Percentagem de regeneração de explantes cotiledonares de melão, cultivar 'Gaúcho', em função do tempo de permanência das sementes nos meios germinativos.

das concentrações de BAP nos meios regenerativos. Com relação à formação de calos, neste trabalho, são enfatizados aqueles provenientes do meio germinativo $\mathrm{G} 1$, pois a resposta desse meio na indução de explantes regenerantes foi maior que os demais, sendo assim observou-se que, quanto menor foi o período de permanência nesse meio, menor foi a influência do aumento da concentração de BAP nos meios regenerativos sobre a taxa de indução de calos (Figura 5). Maiores indução de calos (36,00 e 29,00\%) ocorreram

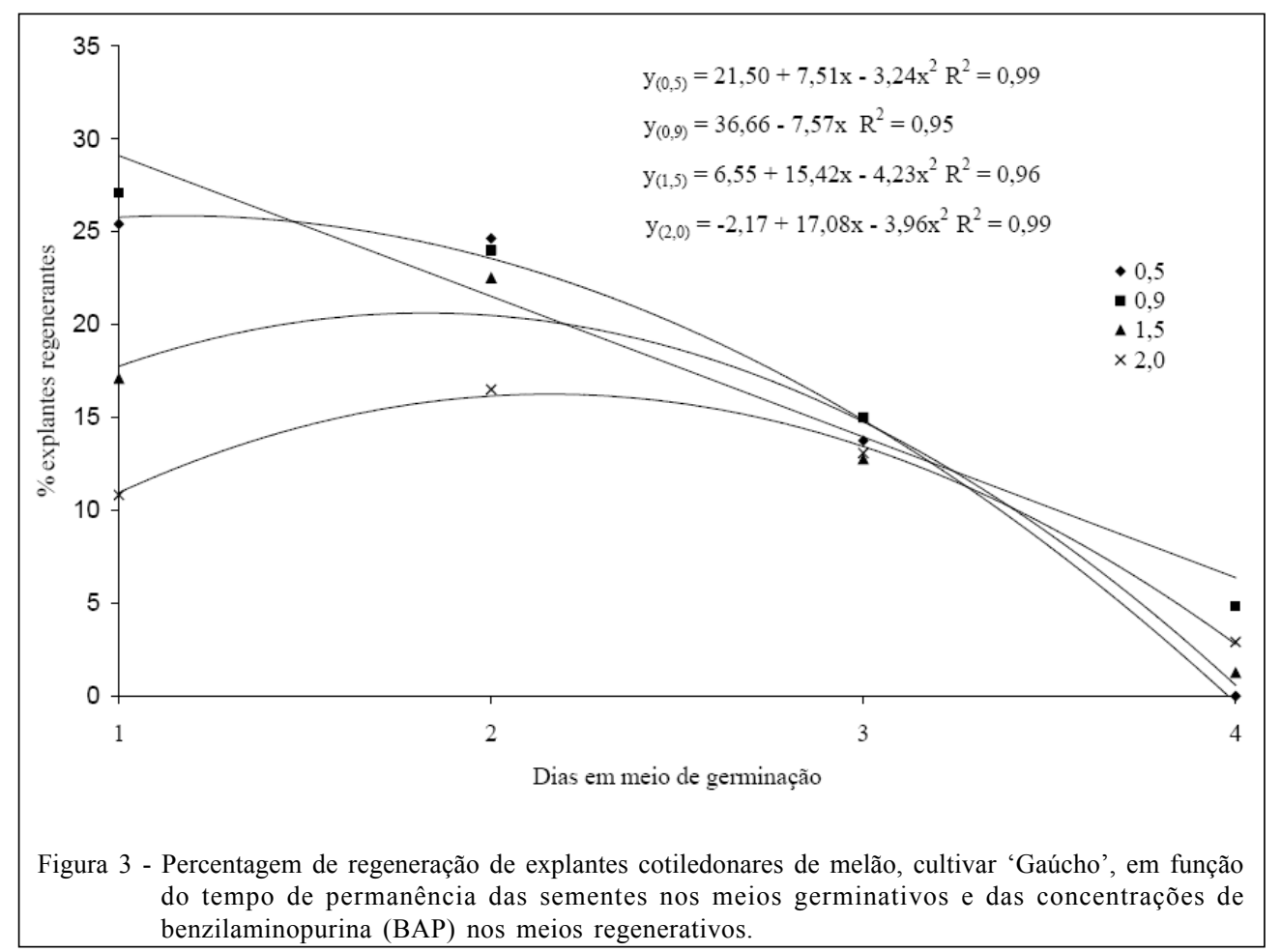

Ciência Rural, v.40, n.5, mai, 2010. 


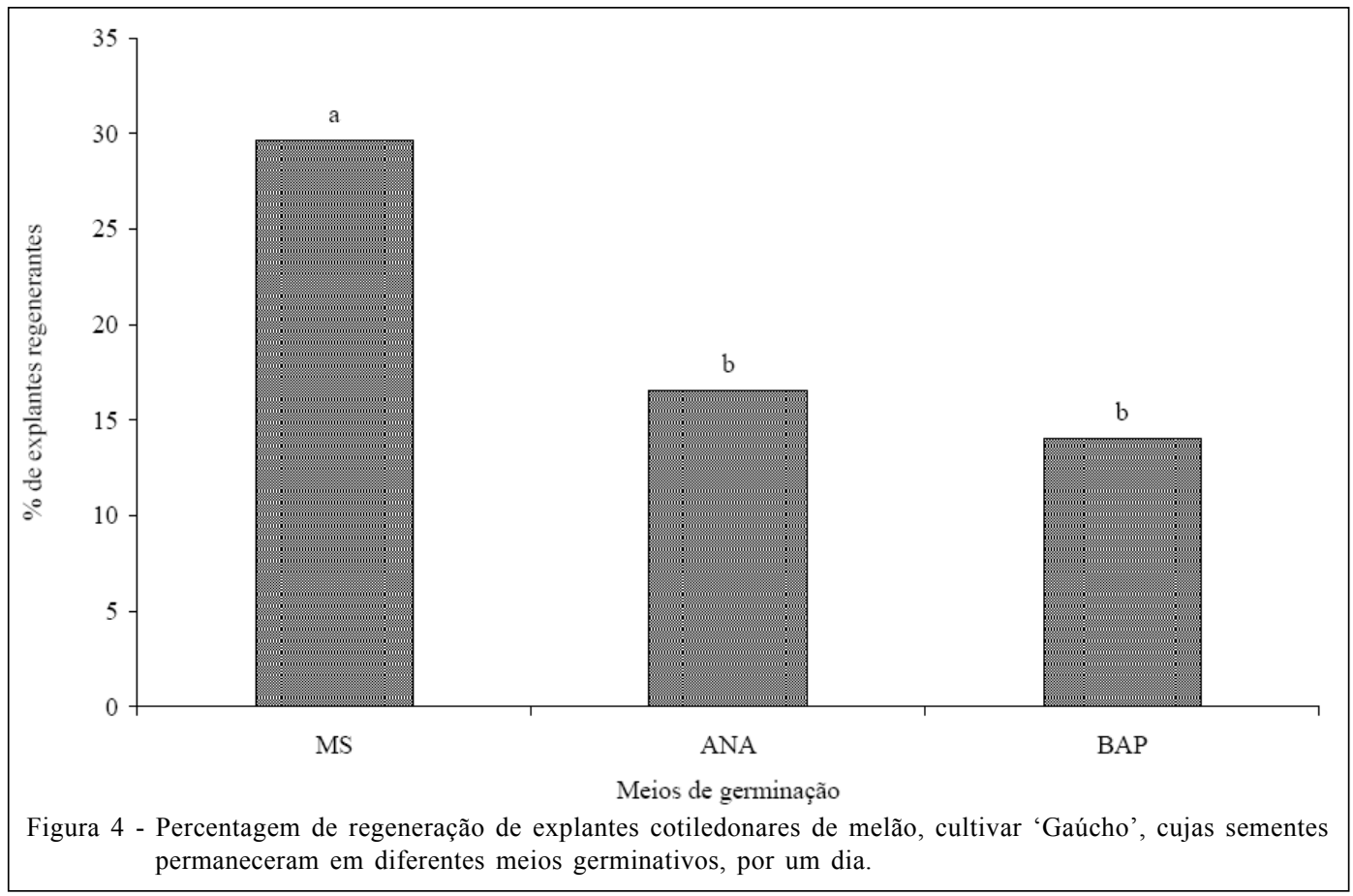

nos explantes inoculados no meio regenerativo contendo $1,5 \mathrm{mg} \mathrm{L}^{-1}$ de BAP e oriundos de sementes mantidas por três e quatro dias nos meios germinativos, respectivamente. Isso também ocorre nos meios germinativos G2 e G3, pois, com o aumento da permanência nesses meios e o aumento da concentração de BAP, no meio regenerativo, também ocorreu um acréscimo da formação de calos.

Os resultados obtidos neste trabalho indicam que explantes mantidos por menor tempo nos

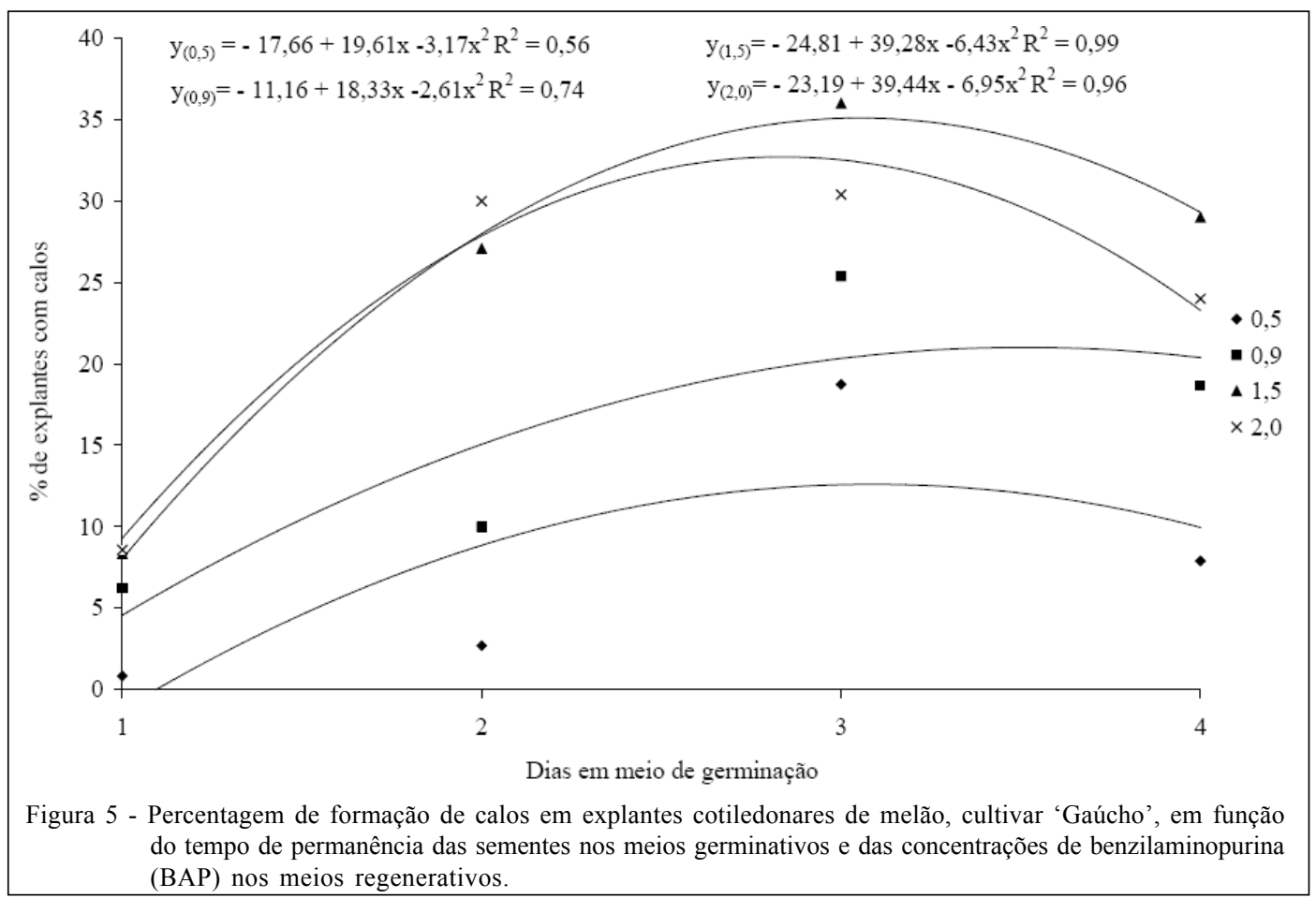

Ciência Rural, v.40, n.5, mai, 2010. 
meios germinativos apresentam maior capacidade regenerativa, ocorrendo o inverso quanto à formação de calos, os quais podem induzir aumento na variação somaclonal das brotações regeneradas (BAIRU et al., 2006), que seria indesejável no processo de transformação genética. PEREIRA et al. (1999), trabalhando com melão das cultivares 'Gaúcho' e 'Imperial', verificaram a formação de calos acima de $90 \%$ em todos os seus tratamentos. Segundo ROUSTAN et al. (1992) e FICCADENTI et al. (1995), a calogênese ocorreria juntamente com a formação de gemas (Figura 1B). Possivelmente, o emprego de baixas concentrações de BAP, neste trabalho, juntamente com ABA, tenha determinado menor formação de calos nos explantes e organogenese direta de gemas e/ou brotações e, posteriormente, planta (Figura 1C e D, respectivamente).

Os resultados aqui obtidos confirmam e evidenciam que as taxas regenerativas da cultivar 'Gaúcho' são inferiores a de outros genótipos mais responsivos, como as cultivares do tipo cantalupensis, com 70 a 80\% de regeneração (GUIS et al., 1997). Esses dados corroboram a afirmação de FICCADENTI et al. (1995) de que a resposta morfogenética em melão é significativamente afetada pelo genótipo.

\section{CONCLUSÕES}

Para a indução mais eficiente de gemas e/ou brotações em explantes cotiledonares de melão, cultivar 'Gaúcho', é necessário utilizar-se de meios para a germinação das sementes sem reguladores de crescimento e meios de regeneração com as menores concentrações de 6-benzilaminopurina, bem como cotilédones obtidos a partir de sementes germinadas por 24 horas.

\section{REFERÊNCIAS}

BAIRU, M. et al. The effect of plant growth regulators on somaclonal variation in Cavendish banana (Musa AAA cv. "Zelig"). Scientia Horticulturae, v.108, p.347-351, 2006. Disponível em: <http:// apps.isiknowledge.com/summary.do?qid=6\&product $=$ UA\&SI $\mathrm{D}=3 \mathrm{Ech} \%$ 40LncMA5KepK15FF\&search mode=Refine $>$. Acesso em: 15 dez. 2008. doi:10.1016/j.scienta.2006.01.039.

DANG, W.; WEI, Z.M. Hight frequency plant regeneration from the cotyledonary node of common bean. Biologia Plantarum, v.53, p.312-316, 2009. Disponível em: <http:// www.springerlink.com/content/b45872037173u547/>. Acesso em: 15 de ago. 2009. doi: 10.1007/s10535-009-0056-5.

DIRKS, R.; VAN BUGGENUM, M. In vitro plant regeneration from leaf and cotyledon explants of Cucumis melo L. Plant Cell
Reports, New York, v.7, p.626-627, 1989. Disponível em: <https:/ /commerce.metapress.com/content/u351k43766237v04/resources e cured $/$ ? target $=$ fulltext.pdf \& sid $=$ us b kxtufpy c 4 zs45kqmygp45\&sh=www.springerlink.com>. Acesso em: 25 jan. 2008. doi: 10.1007/BF00272045.

FICCADENTI, N. et al. Genotype and medium affect shoot regeneration of melon. Plant Cell Tissue and Organ Culture, v.40, p.293-295, 1995. Disponível em: <http:// www.springerlink.com.w10046.dotlib.com.br/content/ $\mathrm{km} 7244708200 /$ ?sortorder $=$ asc\&p_o=10>. Acesso em: 12 abr. 2007. doi: $10.1007 / \mathrm{BF} 0004813 \overline{7}$

GRAY, D.J. et al. High- frequency somatic embryogenesis from quiescent seed cotyledons of Cucumis melo. Journal American Society for Horticultural Science, v.118, p.425$432,1993$.

GUIS, M. et al. An efficient method for the production of diploids Cantaloup Charentais Melon (Cucumis melo L. var. cantalupensis) by somatic embryogenesis. Scientia Horticulturae, v.69, p.199206, 1997. Disponível em: <http://apps.isiknowledge.com/ full_record.do?product $=U A \&$ search_mode $=$ Refine $\&$ qid $=$ $2 \&$ S I D $=4$ A b d L G A p B f J 6 o A $N$ d 9 $\mathrm{MN} \&$ page $=7 \&$ doc $=70 \&$ colname $=$ WOS $>$. Acesso em: 16 nov. 2006. doi: 10.1016/S0304-4238(97)00002-2.

KATHAL, R.S.P. et al. Regeneration of shoots from hypocotyl callus of Cucumis melo cv. 'Pusa sharbati'. Journal Plant Physiology, v.126, p.59-62, 1995.

KIRKBRIDE, J.H. Jr. Biosystematic monograph of genus Cucumis (Cucurbitaceae). Bonne, North Carolina: Parkway Publishers, 1993. 159p.

LESHEM, B. Polarity and responsive regions for regeneration in the culture melon cotyledons. Journal Plant of Physiology, v. 135, p. $237-239,1989$.

LIU, X.; PIJUT, P.M. Plant regeneration from in vitro leaves of mature black cherry (Prunus serotina). Plant Cell, Tissue Organ Culture, v.94, p.113-123, 2008. Disponível em: $<$ http://www.springerlink.com.w 10046 .dotlib.com.br/ c o n t e n t / b 7 q $8 \begin{array}{lllllllllllll} & \text { j } & 0 & 2 & 3 & 5 & 3 & 9 & 6 & 2 & 4 & 8\end{array} /$ $? \mathrm{p}=9 \mathrm{ab} 392541 \mathrm{a} 2349 \mathrm{~d} 0 \mathrm{a} 91314 \mathrm{f} 61 \mathrm{c} 71997 \mathrm{c} \& \mathrm{pi}=1>$. Acesso em: 20 mar. 2009. doi: 10.1007/s11240-008-9393-x.

MACHADO, A.A.; CONCEIÇÃO, A.R. Sistema de análise de estatística para windows. WinstaT. Versão 2.0. Pelotas: UFPEL, 2003.

MOLINA, R.V.; NUEZ, F. Correlated response of in vitro regeneration capacity from different source of explants in Cucumis melo. Plant Cell Reports, v.15, p.129-132, 1995a. Disponível em: <http:// apps.isiknowledge.com/full_record.do?product=UA\&search_mode=Refi $\mathrm{n}$ e $\& \mathrm{q}$ i d $=11 \& \mathrm{~S} \mathrm{I} \mathrm{D}=4 \mathrm{~A}$ b d L G A p B f J 6 o A Nd9MN\&page $=4 \&$ doc $=39 \&$ colname $=$ WOS $>$. Acesso em: 20 mar. 2007. doi: 10.1007/BF01690269.

MURASHIGE, T.; SKOOG, F. A revised medium for rapid growth and biossays with tabacco tissue cultures. Physiological Plant, v. 15, p.473-497, 1962. 
NIEDZ, R.P. et al. Factors affecting shoot regeneration from cotiledonary explants of Cucumis melo. Plant Cell Tissue and Organ Culture, v.18, p.313-319, 1989

PECH, J.C. et al. Physiologie des fruits à noyau lors du développement et de la maturation sur l'arbre. In. SEMINARIO CELEBRADO EN LA FIRA DE LLEIDA, 1994, Lleida-España. Actas... IRTA: CIHEAL y Ajuntament de Lleida, 1994. p.1735 .

PEREIRA, J.E.S. et al. Efeito de diferentes meios de cultura na regeneração in vitro do meloeiro (Cucumis melo L.) 'Gaúcho' e 'Hales Best Imperial'. Revista Ciência Agrotécnica de Lavras, v.23. n.3, p.540-546, 1999.

ROUSTAN, J.P. et al. Enhancement of shoot regeneration from cotyledons of Cucumis melo by $\mathrm{AgNO}_{3}$, an inhibitor of ethylene action. Journal of Plant Physiology, n.140, p.485488, 1992

SILVA, J.A. T. et al. Characterization of ripening behavior in transgenic melons expressing na antisense 1-aminocyclopropane1-carboxylate (ACC) oxidase gene from Apple. Postharvest Biology and Technology, v.32, p.263-268, 2004.

YADAV, R.S. et al. High frequency shoot regeneration from leaf explants of muskmelon. Plant Cell, Tissue Organ Culture, v.45, p.207-214, 1996. Disponível em: $<$ http://www.springerlink.com.w10046.dotlib.com.br/

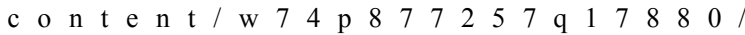
? $\mathrm{p}=9 \mathrm{e} 186 \mathrm{~d} 3 \mathrm{cac} 904 \mathrm{a} 5 \mathrm{f} 8 \mathrm{ae} 86 \mathrm{f} 4495 \mathrm{e} 73445 \& \mathrm{pi}=4>$. Acesso em: 19 mar. 2007. doi: 10.1007/BF00043632. 